\title{
Occurrence of Amblyomma sp. (Acari: Ixodidae) in Tropidurus hispidus (Spix, 1825) (Squamata: Tropiduridae) in Parque Nacional Serra de Itabaiana, Sergipe, Brazil
}

\author{
Daniel Oliveira Santana ${ }^{1}$, Francis Luiz Santos Caldas ${ }^{1,2}$, Lucas Barbosa de \\ Queiroga Cavalcanti ${ }^{1}$, Fabíola Fonseca Almeida Gomes ${ }^{3}$, Bruno Duarte da Silva ${ }^{3}$, \\ Rafael Alves dos Santos ${ }^{3} \&$ Renato Gomes Faria ${ }^{3}$
}

(1) Universidade Federal da Paraíba, Departamento de Sistemática e Ecologia, Programa de Pós-Graduação em Ciências Biológicas (Zoologia), Cidade Universitária, João Pessoa 58051-900, Paraíba, Brazil. E-mail: danielbioufs@yahoo.com.br

(2) Faculdades Integradas de Sergipe, Largo Glicério Cerqueira 387, Centro, Tobias Barreto 35690-000, Sergipe, Brazil. E-mail: francisluiz_bio@hotmail.com

(3) Universidade Federal de Sergipe, Departamento de Ecologia, Programa de Pós-Graduação em Ecologia e Conservação, Rosa Elze, São Cristóvão 49100-000, Sergipe, Brazil. E-mail: biola_gomes@hotmail.com

Santana D.O., Caldas F.L.S., Cavalcanti L.B.Q., Gomes F.F.A., Silva B.D., Santos R.A. \& Faria R.G. (2017) Occurrence of Amblyomma sp. (Acari: Ixodidae) in Tropidurus hispidus (Spix, 1825) (Squamata: Tropiduridae) in Parque Nacional Serra de Itabaiana, Sergipe, Brazil. Pesquisa e Ensino em Ciências Exatas e da Natureza, 1(2): 99-103.

Ocorrência de Amblyomma sp. (Acari: Ixodidae) em Tropidurus hispidus (Spix, 1825) (Squamata: Tropiduridae) no Parque Nacional Serra de Itabaiana, Sergipe, Brasil

Resumo: Lagartos frequentemente são parasitados por espécies de Acari (ácaros e carrapatos). No presente estudo relatamos a ocorrência de Amblyomma sp. (carrapato) parasitando um indivíduo juvenil de Tropidurus hispidus (Spix, 1825). A observação foi realizada no Parque Nacional Serra de Itabaiana (PNSI) no estado de Sergipe, nordeste do Brasil.

Palavras chave: Parasita, carrapato, Amblyomma, bolsa de ácaro, Tropidurus.

Abstract: Lizards are often parasitized by Acari species (mites and ticks). In this study we report the occurrence of a specimen of tick (Amblyomma sp.) parasitizing a juvenile individual of Tropidurus hispidus (Spix, 1825) in Parque Nacional Serra de Itabaiana (PNSI) in the state of Sergipe, northeastern Brazil.

Key words: Parasites, ticks, Amblyomma, mite pocket, Tropidurus.

Mites and ticks are parasites on plenty of animal species, mostly vertebrates which include reptiles (Urquhart et al. 1998; Labruna et al. 2007). These ectoparasites use their mouthpiece to fix and feed on their hosts, while some inject toxins which could affect host metabolism by causing negative consequences (i.e., weakness, low rates of hematocrits, paralysis, death) (Cupp 1991; Barbosa et al. 2006). These parasites were found on many species from Brazilian herpetofauna, such as frogs, snakes, turtles, alligators and other lizards (Amorim et al. 1996; Lampo \& Bayliss 1996; Evans et al. 2000; Brum \& Costa 2003; Barbosa et al. 2006; Onofrio et al. 2006; Labruna et al. 2007; Ahid et al. 2009; Fischer et al. 2009; Morais et al. 2010; Viana et al. 2012). Lizards are often parasitized by Acari (Bauer et al. 1990, 1993; Delfino et al. 2011). For instance, some Tropidurus Wied-Neuwied, 1825 species present skin folds in many different 
body regions, which consists on structures called "mite pockets" (Rodrigues 1987; Bauer et al. 1990, 1993; Delfino et al. 2011). Tropidurus hispidus (Spix, 1825) is the largest genus species, presenting an insectivore diet and a sit-and-wait foraging mode (Rodrigues 1987; Vitt et al. 1996; Colli \& Paiva 1997; Santana et al. 2011a,b). These lizards are usually found on rocky outcrops (Vitt et al. 1996, 1997; Van-Sluys et al. 2004; Santana et al. 2014). Nevertheless, they can also be found on trees, fallen logs, sandy soils, forest borders and anthropic habitats, being a generalist species (Rodrigues 1987; Vitt 1995; Carvalho et al. 2005; Santana et al. 2014; Gomes et al. 2015). This species is widely distributed (Yonenaga-Yassuda et al. 1988), occuring from Northeast South America (Venezuela) to South of Minas Gerais, Brazil (Rodrigues 1987; Ávila-Pires 1995).

Amblyomma Koch, 1844 is a tick genus of the family Ixodidae Murray, 1877, distributed worldwide, with exception of Antarctica (Fischer et al. 2009). These ticks are usually called hard ticks, by the presence of a hard chitinous shield (Cupp 1991; Labruna et al. 2005). They are quite large when compared to other mites, and present: an ornamented back, colored leg bands, eyes and garlands (Urquhart et al. 1998; Onofrio et al. 2006). Amblyomma species frequently parasite vertebrates (Evans et al. 2000), majorly birds, mammals (Sinkoc et al. 1997), reptiles (Carothers \& Jaksic 2001) and frogs (Urquhart et al. 1998; Brum \& Costa 2003; Antonucci et al. 2011; Antonucci et al. 2012).

We found an adult specimen of hard tick (Amblyomma sp.), parasitizing a juvenile Tropidurus hispidus $(\mathrm{SVL}=66.0 \mathrm{~mm}$; to the nearest $1 \mathrm{~mm}$ ). The lizard was captured using a lace made of floss and a "telescopic" fishing pole on a forest border. The parasite was fixed on the right side of the animal and occupied the entire neck mite pocket (Figure 1). The tick was removed, formalized (4\%) and preserved on alcohol $70 \%$. The tick was analyzed and identified on laboratory, using a stereomicroscope and according to the dichotomous keys of Onofrio et al. (2006). The observation was made on Year 2009, February $26^{\text {th }}$, at Parque Nacional Serra de Itabaiana (PNSI; 10 $0^{\circ} 0^{\prime} \mathrm{S}, 37^{\circ} 25^{\prime} \mathrm{W}$ ), a transition zone between Caatinga and Atlantic Forest, located $35 \mathrm{~km}$ from Aracaju city, Sergipe state, Northeast Brazil.

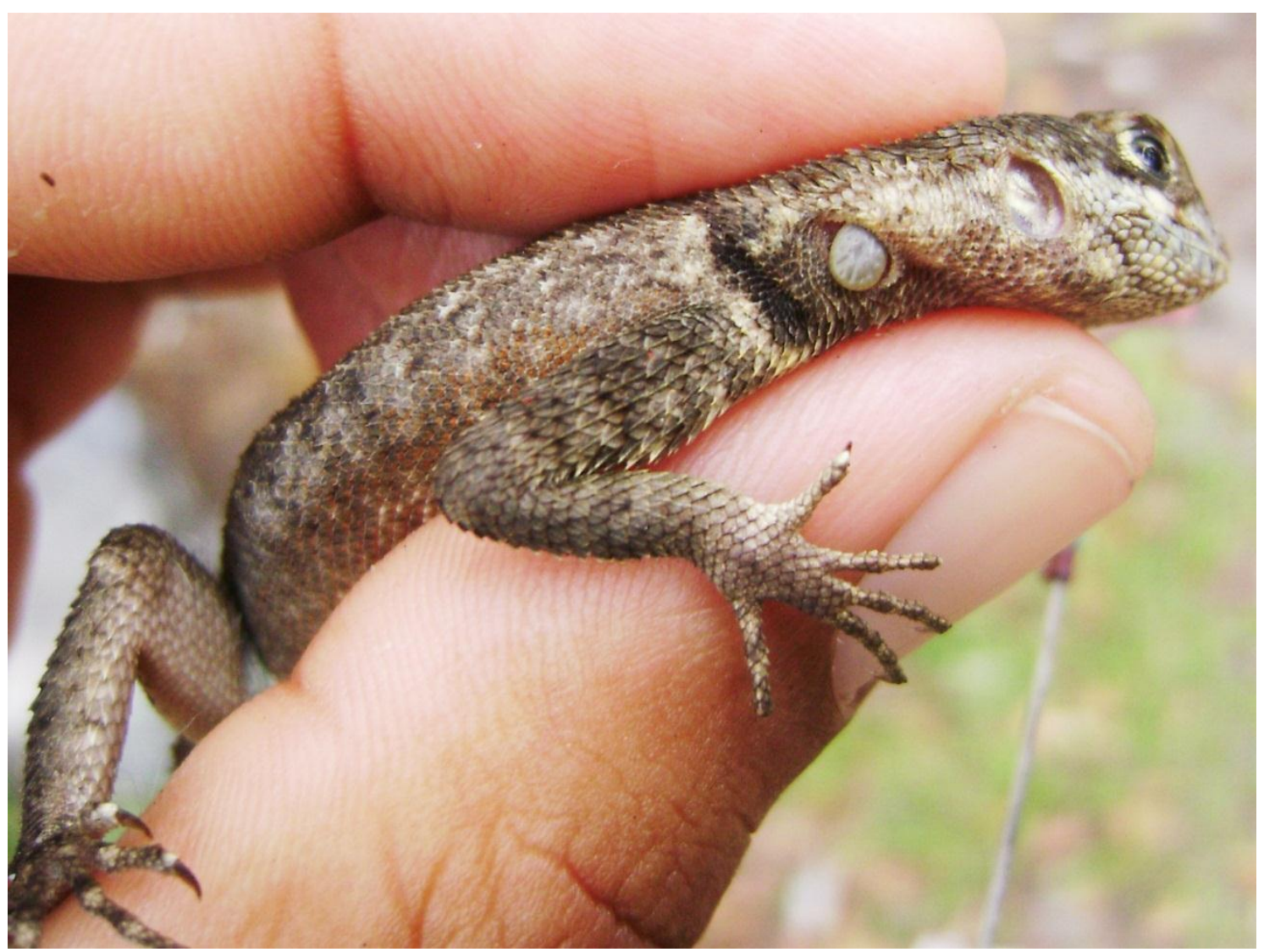

Figure 1. Juvenile specimen of Tropidurus hispidus being a host of Amblyomma sp. at Parque Nacional Serra de Itabaiana, Sergipe, Brazil (Photo: Daniel Oliveira Santana). 
In Brazil, mostly mite studies are limited to short communications from random observations and/or a single register, such as this paper (Dantas-Torres et al. 2005; Lopes et al. 2010; Viana et al. 2012). Concerning Tropidurus being a host of Amblyomma, A. rotundatum Koch, 1844 was found on natural conditions parasitizing an Tropidurus species, found by Labruna et al. (2005) but the lizard species was not specified on the given study.

Ecological relationships between lizards and their parasites are still unclear for most species, making such considerations difficult to make (Silva \& Araújo 2008). Also, the knowledge of Amblyomma parasitism on wild reptiles is limited, being this communication a contribution to a new register concerning this lack of information. In this study, we found that Tropidurus hispidus can be a host for Amblyomma sp.

\section{Acknowledgments}

We thank to Instituto Brasileiro do Meio Ambiente e Recursos Naturais Renováveis IBAMA, by collecting permit consession (permit \# 10504-1). To the employees from Parque Nacional Serra de Itabaiana for their support and to CNPq (Conselho Nacional de Desenvolvimento Científico e Tecnológico) and CAPES (Coordenação de Aperfeiçoamento de Pessoal de Nível Superior) by the fellowship consessions to Daniel Oliveira Santana, Francis Luiz Santos Caldas, Fabíola Fonseca Almeida Gomes, Bruno Duarte da Silva e Rafael Alves dos Santos. We are also grateful to the anonymous reviewers for critically reviewing the manuscript.

\section{References}

Ahid S.M.M., Fonseca Z.A.A.S., Ferreira C.G.T., Martins T.F. \& Oliveira M.F. (2009) Parasitismo de Amblyomma rotundatum (Koch) (Acari: Ixodidae) em Bufo marinus (Linnaeus) (Anura: Bufonidae), em Mossoró, Rio Grande do Norte, Brasil. Revista Brasileira de Zoociências, 11(2): 153-156.

Amorim M., Gazêta G.S., Cristalli R.S. \& Serra-Freire N.M. (1996) Biology of Amblyomma rotundatum Koch, 1844 (Acari: Ixodidae) under laboratory conditions: infestation dynamics of unengorged female in Crotalus durissus (L.). Revista Universidade Rural. Série Ciências da Vida, 18(1/2): 35-39.

Antonucci A.M., Marcantonio A.S., França F.M. \& Pereira J.R. (2012) Ocorrência de Amblyomma rotundatum Koch, 1844 (Acari: Ixodidae) em Bufo ictericus Spix, 1824 (Rinella icterica) (Anura: Bufonidae) no Vale do Paraíba, São Paulo, Brasil. Natureza on line, 10(1): 5-6.

Antonucci A.M., Oda F.H., Signorelli L., Santana N.F. \& Mendes M.C. (2011) Parasitismo de Amblyomma rotundatum (Koch, 1844) (Acari: Ixodidae) em Rhinella schneideri (Werner, 1894) (Anura: Bufonidae) no estado do Paraná, Brasil. Natureza on line, 9(3): 103-105.

Ávila-Pires T.C.S. (1995) Lizards of Brazilian Amazonia (Reptilia: Squamata). Zoologische Verhandelingen, 299(1): 1-706.

Barbosa A.R., Silva H., Albuquerque H.N. \& Ribeiro I.A.M. (2006) Contribuição ao estudo parasitológico de jibóias, Boa constrictor constrictor Linnaeus, 1758, em cativeiro. Revista de Biologia e Ciências da Terra, 6(2): 1-18.

Bauer A.M., Russell A.P. \& Dollahon N.R. (1990) Skin folds in the gekkonid lizard genus Rhacodactylus: a natural test of the damage limitation hypothesis of mite pocket function. Canadian Journal of Zoology, 68(6): 1196-1201.

Bauer A.M., Russell A.P. \& Dollahon N.R. (1993) Function of the mite pockets of lizards: a reply to EN Arnold. Canadian Journal of Zoology, 71(4): 865-868.

Brum J.G.W. \& Costa P.R.P. (2003) Confirmação da ocorrência da Amblyomma rotundatum Koch, 1844 (Acari: Ixodidae) no Rio Grande do Sul. Arquivos do Instituto Biológico, 70(1): 105-106.

Carothers J.H. \& Jaksic F.M. (2001) Parasite loads and altitudinal distribution of Liolaemus lizards in the central Chilean Andes. Revista Chilena de Historia Natural, 74(3): 681-686. doi: 10.4067/S0716-078X2001000300013. 
Carvalho C.M., Vilar J.C. \& Oliveira F.F. (2005) Répteis e Anfíbios (p. 39-61). In: Carvalho C.M. \& Vilar J.C. (Eds). Parque Nacional Serra de Itabaiana - Levantamento da Biota. Aracaju: Ibama, Biologia Geral e Experimental - UFS. 131 p.

Colli G.R. \& Paiva M.S. (1997) Estratégias de forrageamento e termorregulação em lagartos do cerrado e savanas amazônicas (p. 224-231). In: Leite L.L. \& Saito C.H. (Eds). Contribuição ao Conhecimento Ecológico do Cerrado. Brasília: Universidade de Brasília. 325 p.

Cupp E.W. (1991) Biology of Ticks. Veterinary Clinics of North America: Small Animal Practice, 21(1): 1-26. doi: 10.1016/S0195-5616(91)50001-2

Dantas-Torres F., Oliveira-Filho E.F., Souza B.O.F. \& Sá F.B. (2005) First record of Amblyomma rotundatum Koch, 1844 (Acari: Ixodidae) parasitizing Crotalus durissus cascavella (Wagler, 1824) (Squamata: Viperidae) in the state of Pernambuco, Brazil. Arquivos do Instituto Biológico, 72(3): 389-390.

Delfino M.M.S., Ribeiro S.C., Furtado I.P., Anjos L.A. \& Almeida W.O. (2011) Pterygosomatidae and Trombiculidae mites infesting Tropidurus hispidus (Spix, 1825) (Tropiduridae) lizards in northeastern Brazil. Brazilian Journal of Biology, 71(2): 549-555.

Evans D.E., Martins J.R. \& Guglielmone A.A. (2000) A review of the ticks (Acari, ixodida) of Brazil, their hosts and geographic distribution-1. The state of Rio Grande do Sul, southern Brazil. Memórias do Instituto Oswaldo Cruz, 95(4): 453-470.

Fischer C.D.B., Mottin V.D., Heerdt M., Filadelfo T., Ceresér V.H., Queirolo M.T. \& Allgayer M.C. (2009) Amblyomma dissimile (Acari: Ixodidae) em Hydrodynastes gigas (Squamata: Colubridae) no estado Mato Grosso do Sul, Brasil - Nota Prévia. Brazilian Journal of Veterinary Research and Animal Science, 46(5): 400-403.

Gomes F.F.A., Caldas F.L.S., Santos R.A., Silva B.D., Santana D.O., Rocha S.M., Ferreira A.S. \& Faria R.G. (2015) Patterns of space, time and trophic resource use by Tropidurus hispidus and T. semitaeniatus in an area of Caatinga, northeastern Brazil. The Herpetological Journal, 25(1): 27-39.

Labruna M.B., Ahid S.M.M., Soares H.S. \& Suassuna A.C.D. (2007) Hyperparasitism in Amblyomma rotundatum (Acari: Ixodidae). Journal of Parasitology, 93(6): 1531-1532.

Labruna M.B., Terrassini F.A. \& Camargo L.M.A. (2005) First report of the male of Amblyomma rotundatum (Acari: Ixodidae) from a field-collected host. Journal of medical entomology, 42(6): 945-947.

Lampo M. \& Bayliss P. (1996) The impact of ticks on Bufo marinus from native habitats. Parasitology, 113(2): 199-206. doi: 10.1017/S0031182000066440

Lopes S.G., Andrade G.V. \& Costa-Júnior L.M. (2010) A first record of Amblyomma dissimile (Acari: Ixodidae) parasitizing the lizard Ameiva ameiva (Teiidae) in Brazil. Revista Brasileira de Parasitologia Veterinária, 19(4): 262-264.

Morais D.H., Strüssmann C., Carvalho V.T. \& Kawashita-Ribeiro R.A. (2010) First record of Amblyomma rotundatum Koch, 1844 (Acari: Ixodidae) parasitizing Paleosuchus palpebrosus Cuvier, 1807 (Reptilia: Crocodylidae), in the western border of Pantanal, Mato Grosso do Sul, Brazil. Herpetology Notes, 3: 133.

Onofrio V.L., Venzal J.M., Pinter A. \& Szabó M.P.J. (2006) Família Ixodidae: características gerais, comentários e chave para gêneros (p. 29-39). In: Barros-Batestti D.M., Arzua M. \& Bechara G.H. (Eds). Carrapatos de importância Médico-Veterinária da Região Neotropical: Um guia ilustrado para identificação de espécies. São Paulo: Vox/ICTTD-3/Butantan. 223 p.

Rodrigues M.T. (1987) Sistemática, ecologia e zoogeografia dos Tropidurus do grupo Torquatus ao sul do Rio Amazonas (Sauria, Iguanidae). Arquivos de Zoologia, 31(3): 105-230. doi: http://dx.doi.org/10.11606/issn.2176-7793.v31i3p105-230

Santana D.O., Caldas F.L.S., Gomes F.F.A., Santos R.A., Silva B.D., Rocha S.M. \& Faria R.G. (2014) Aspectos da História Natural de Tropidurus hispidus (Squamata: Iguania: Tropiduridae) em área de Mata Atlântica, nordeste do Brasil. Neotropical Biology and Conservation, 9(1): 55-61. doi: http://dx.doi.org/10.4013/nbc.2014.91.07 
Santana D.O., Caldas F.L.S., Santos R.A., De-Carvalho C.B., Freitas E.B., Rocha S.M., Noronha M.V. \& Faria R.G. (2011a) Morphometry of hatchlings of Tropidurus hispidus (Spix, 1825) (Squamata: Tropiduridae). Herpetology Notes, 4: 39-40.

Santana D.O., Faria R.G., Ribeiro A.S., Oliveira A.C.F., Souza B.B., Oliveira D.G., Santos E.D.S., Soares F.A.M., Gonçalves F.B., Calasans H.C.M., Vieira H.S., Cavalcante J.G., Marteis L.S., Aschoff L.S., Rodrigues L.C., Xavier M.C.T., Santana M.M., Soares N.M., Figueiredo P.M.F.G., Barretto S.S.B., Franco S.C. \& Rocha S.M. (2011b) Utilização do microhábitat e comportamento de duas espécies de lagartos do gênero Tropidurus numa área de Caatinga no Monumento Natural Grota do Angico. Scientia Plena, 7(4): 001-009.

Silva V.N. \& Araújo A.F.B. (2008) Ecologia dos lagartos brasileiros. Rio de Janeiro: Technical Books. 271 p.

Sinkoc A.L., Brum J.G.W., Müller G., Begrow A. \& Paulsen R.M.M. (1997) Occurence of ixodidae parasites of capybara (Hydrochoeurus hydrochaeris Linnaeus, 1766) in the ecologic area of Taim, Rio Grande-RS, Brazil. Ciência Rural, 27(1): 119-122.

Urquhart G.M., Armour J., Ducan J.L., Dunn A.M. \& Jennings F.W. (1998) Parasitologia Veterinária. $2^{\circ}$ edição. Rio de Janeiro: Guanabara Koogan. 273 p.

Van-Sluys M., Rocha C.F.D., Vrcibradic D., Galdino C.A.B. \& Fontes A.F. (2004) Diet, Activity, and Microhabitat Use of Two Syntopic Tropidurus Species (Lacertilia: Tropiduridae) in Minas Gerais, Brazil. Journal of Herpetology, 38(4): 606-611. doi: http://dx.doi.org/10.1670/218-03N

Viana L.A., Winck G.R., Almeida-Santos M., Telles F.B.S., Gazêta G.S. \& Rocha C.F.D. (2012) New host records for Amblyomma rotundatum (Acari: Ixodidae) from Grussaí restinga, Rio de Janeiro, Brazil. Revista Brasileira de Parasitologia Veterinária, 21(3): 319-322.

Vitt L.J. (1995) The Ecology of Tropical Lizards in the Caatinga of Northeast Brazil. Occasional Papers of the Oklahoma Museum of Natural History, 1: 1-29.

Vitt L.J., Caldwell J.P., Zani P.A. \& Titus T.A. (1997) The role of habitat shift in the evolution of lizard morphology: evidence from tropical Tropidurus. Proceedings of the National Academy of Sciences of the USA, 94(8): 3828-3832.

Vitt L.J., Zani P.A. \& Caldwell J.P. (1996) Behavioural ecology of Tropidurus hispidus on isolated rock outcrops in Amazonia. Journal of Tropical Ecology, 12(1): 81-101.

Yonenaga-Yassuda Y., Kasahara S., Chu T.H. \& Rodrigues M.T. (1988) High-resolution RBGbanding pattern in the genus Tropidurus (Sauria, Iguanidae). Cytogenetics and Cell Genetics, 48(2): 68-71. 